\title{
Study of the redistribution of solute in eutectic lead-tin alloys solidified under high acceleration
} Estudo da redistribuição de soluto em ligas eutéticas de chumbo-estanho solidificadas sob alta aceleração

Plínio Ivo Gama Tenório ${ }^{1}$, Rafael Cardoso Toledo¹, Irajá Newton Bandeira¹, Chen Ying An ${ }^{1}$

\section{ABSTRACT}

With the objective of studying the effects of gravity in the solidification of materials, a centrifugal that can offer an acceleration environment bigger than gravity during the casting process was developed in the Laboratory of Sensors and Materials of the National Institute for Space Research (LABAS/INPE). So, a lead-tin eutectic alloy was tested and solidified in two different accelerations, $1 \mathrm{~g}$ and $9 \mathrm{~g}$ (with $1 \mathrm{~g}$ equal to $9.8 \mathrm{~m} / \mathrm{s}^{2}$ ). This work presents changes caused by the difference in acceleration in the alloy's phases distribution along the sample.

Keywords: Solidification, High gravity, Eutectic alloys.

\section{RESUMO}

Com o objetivo de estudar os efeitos da gravidade na solidificação de materiais foi desenvolvida uma centrífuga no Laboratório Associado de Sensores e Materiais do Instituto Nacional de Pesquisas Espaciais (LABAS/INPE), esse equipamento pode proporcionar um ambiente de acelerações maior que a gravidade terrestre durante o processo de fundição. Com isso, foi ensaiada uma liga de chumbo-estanho eutética, sendo solidificada em duas acelerações diferentes, $1 \mathrm{~g}$ e $9 \mathrm{~g}$ (com $1 \mathrm{~g}$ igual a $\left.9.8 \mathrm{~m} / \mathrm{s}^{2}\right)$. Esse trabalho apresentará como a distribuição das fases da liga ao longo do tarugo foi alterada pela diferença na aceleração.

Palavras-chave: Solidificação, Alta gravidade, Ligas eutéticas. 


\section{INTRODUCTION}

The study of materials processed in centrifuges improves the understanding on influence of acceleration and convection in materials processing. Large centrifuges are expensive and rarely available for crystal growth and solidification experiments. To overcome this difficulty, a small centrifuge with an electric tubular furnace was designed and built at LABAS/INPE, which provides an acceleration ranging from 1 to 10 times the Earth gravity (Fig. 1) 1,2. The scope of this work is to study the influence of the high gravity on the redistribution of solute due to effects of the buoyancy-driven convection. The axial composition of the samples was analyzed by densitometry and energy dispersive spectrometry (EDS). The PbSn eutectic alloy is a material that provides convenient physical properties such as low melting point $\left(183^{\circ} \mathrm{C}\right)$, low vapor pressure, and does not react with the surface of the quartz ampoule, being an ideal material for solidification studies of regular eutectic alloys ${ }^{3}$.

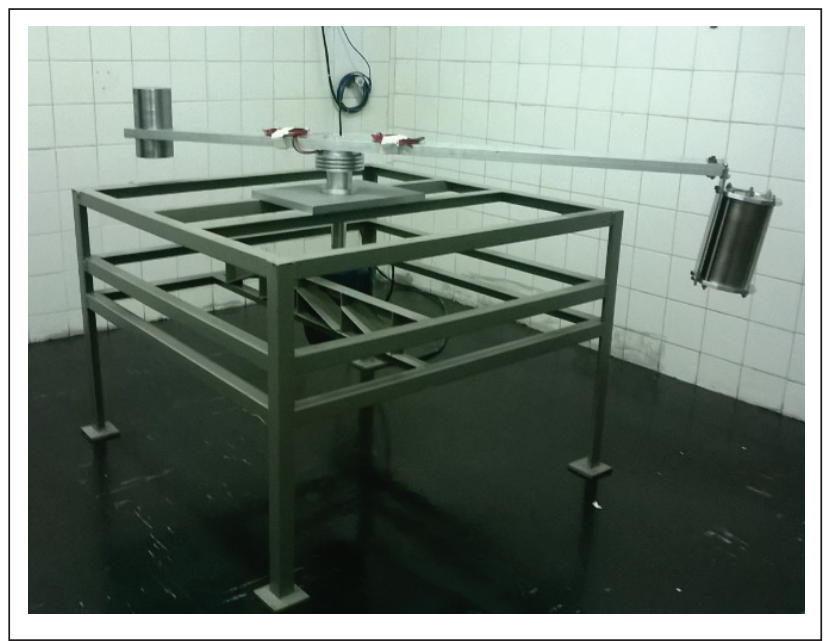

Figure 1: Centrifuge (with furnace at the right side) of LABAS/INPE.

\section{EXPERIMENTAL}

The solidification experiments of $\mathrm{Pb}_{25,9} \mathrm{Sn}_{74,1}$ (at \%) eutectic alloy was carried out in the furnace at the centrifuge (Fig. 2). For this, a quartz ampoule $(10 \times 100 \mathrm{~mm})$ with $20 \mathrm{~g}$ of the alloy mass was sealed at a pressure of $5.10^{-6}$ Torr.

The solidification experiments were carried out in two accelerations: $1 \mathrm{~g}$ and $9 \mathrm{~g}$, where $\mathrm{g}$ is the gravity acceleration on Earth $\left(9.8 \mathrm{~m} / \mathrm{s}^{2}\right)$. The thermal parameters were the same in both cases: the furnace was heated with a set temperature of $200^{\circ} \mathrm{C}$ for $1 \mathrm{~h}$, after this, the temperature controller was turned off and the sample was left in the furnace until solidified (Fig. 3). In the $9 \mathrm{~g}$ experiment the motor turned on at $92 \mathrm{rpm}$ and kept running at constant speed during the whole solidification process.

After solidification tests the alloys were metallographically prepared for analysis. This preparation consists on slicing the sample to analyze the solute distribution along of the alloy and polishing the divided parts for EDS (Fig. 4).

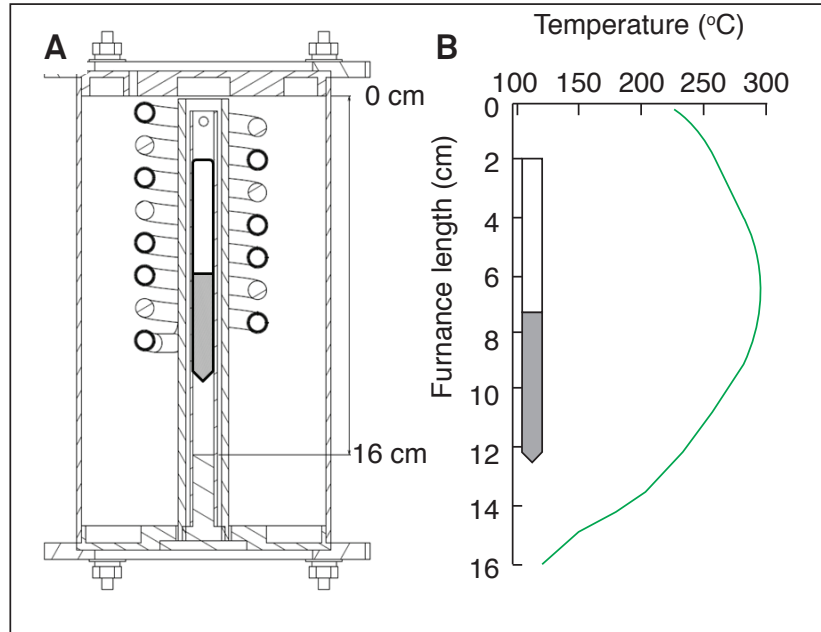

Figure 2: (A) Ampoule position inside of the furnace; (B) ampoule position in the temperature profile of the furnace.

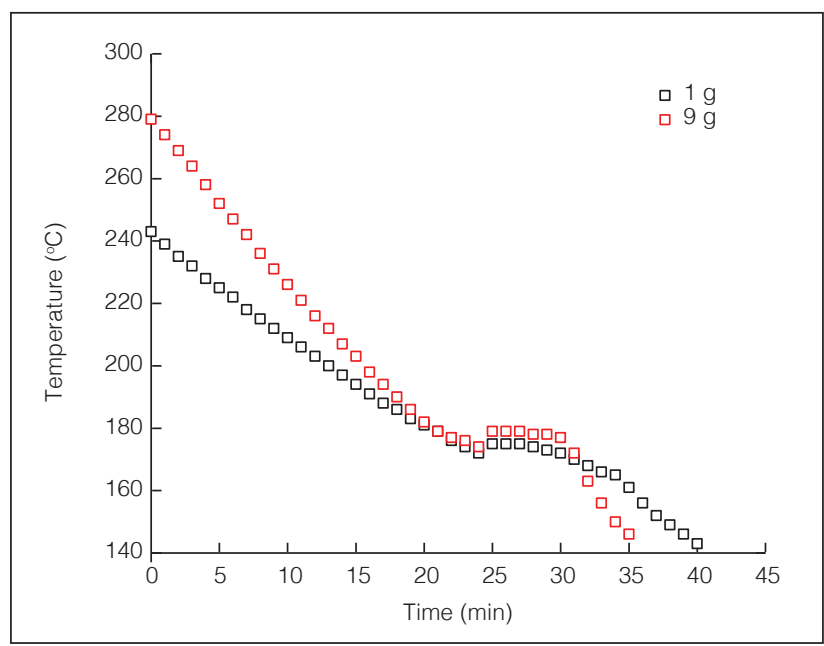

Figure 3: Experimental cooling curves at $1 \mathrm{~g}$ and $9 \mathrm{~g}$.

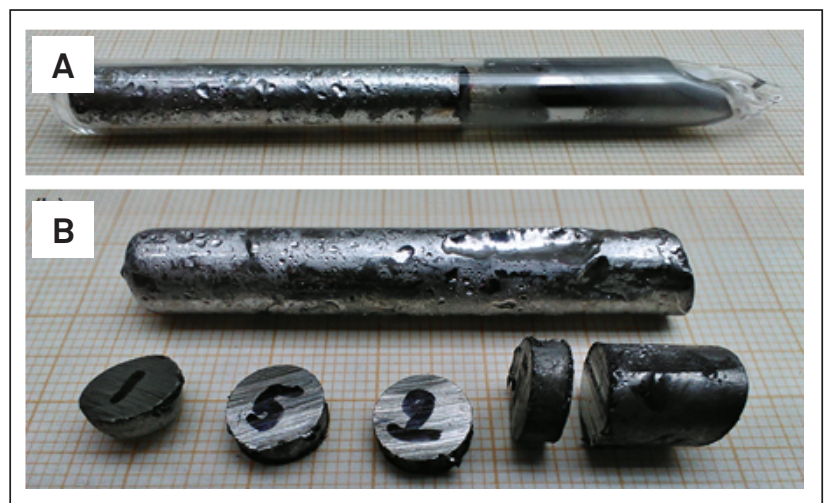

Figure 4: PbSn eutectic alloy (A) sealed in quartz ampoule; (B) after solidification test.

\section{RESULTS AND DISCUSSION}

The lead composition profile of the samples was obtained by densitometry (Archimedes principle) using $\mathrm{CCl}_{4}\left(1.592781 \mathrm{~g} / \mathrm{cm}^{3}\right)$ as fluid and measured along the axial direction (Fig. 5) ${ }^{4}$. 


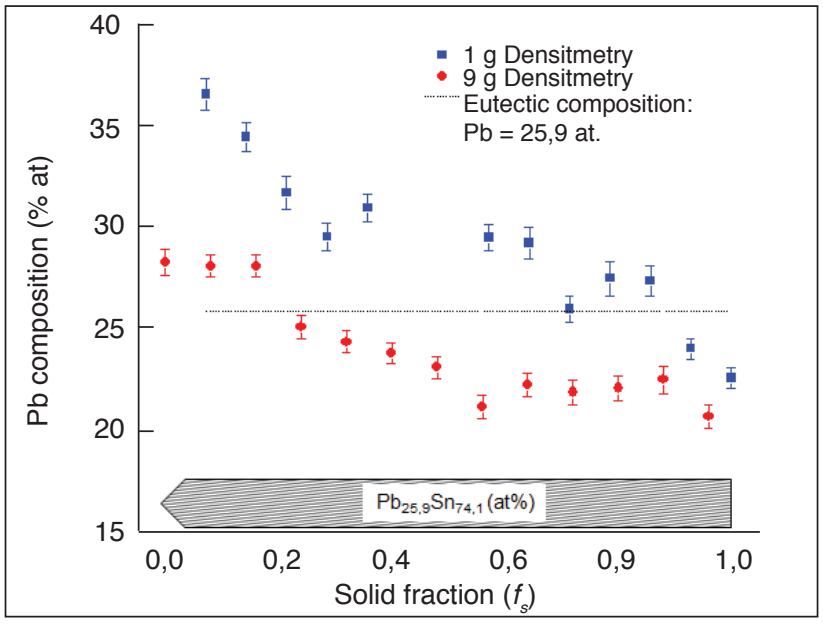

Figure 5: Lead composition profile by densitometry.

In the initial solid fractions of the samples there are solute $(\mathrm{Pb})$ accumulation, which could be caused by the gravity influence in the cast alloy or/and during the solidification processes (convection and sedimentation).

With data measured by densitometry, using the small parts density weighted average, could be determined the real alloys composition (Fig. 4). This determination is important for comparison between the tested alloys. In this case, it has two types of $\mathrm{PbSn}$ alloys, the $1 \mathrm{~g}$ is hypoeutectic, and the $9 \mathrm{~g}$ is hypereutectic, but both cases are nearby the eutectic point.

The analysis by EDS (Fig. 5) shows a smaller difference between both samples, the $1 \mathrm{~g}$ solidified alloy have only primary $a$ and eutectic phase formation in the begging of the sample (where the primary $\alpha$ is from 0 to 0.4 of solid fraction), while the $9 \mathrm{~g}$ have the formation of eutectic, primary $\alpha$ and $\beta$ phase ( $\alpha$ similar to $1 \mathrm{~g}$ and $\beta$ from 0.8 to 1 of solid fraction).

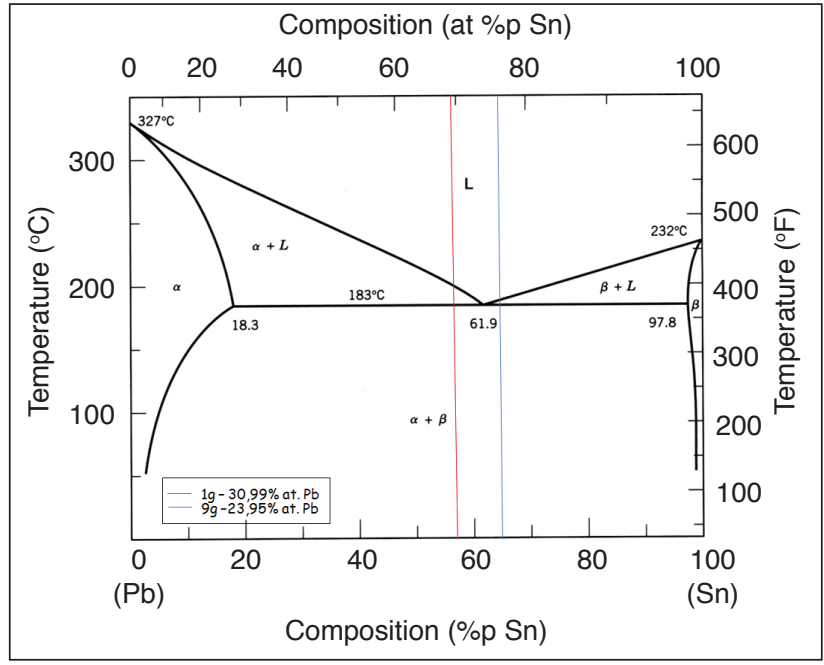

Figure 5: Composition of tested alloys, adapted from Okamoto et al. ${ }^{5}$.

\section{CONCLUSION}

The error in the alloy composition could be related to mass measurement during initial charge preparation or to the samples preparation for experiments. That fact explains why the $1 \mathrm{~g}$ sample has a formation of primary a phase. The $9 \mathrm{~g}$ sample should not have this phase, because it is a hypereutectic alloy, i.e., just the formation of primary $\beta$ and eutectic phase.

The influence of high acceleration during the solidification process could be present in the solute distribution. In both cases the denser phase is present in the sample initial part, aligned with the gravity vector. These effects are caused by the buoyancydriven convection and sedimentation.

Lastly, this work shows that acceleration during the solidification process could control the solute redistribution and the centrifuge can be used to this purpose.

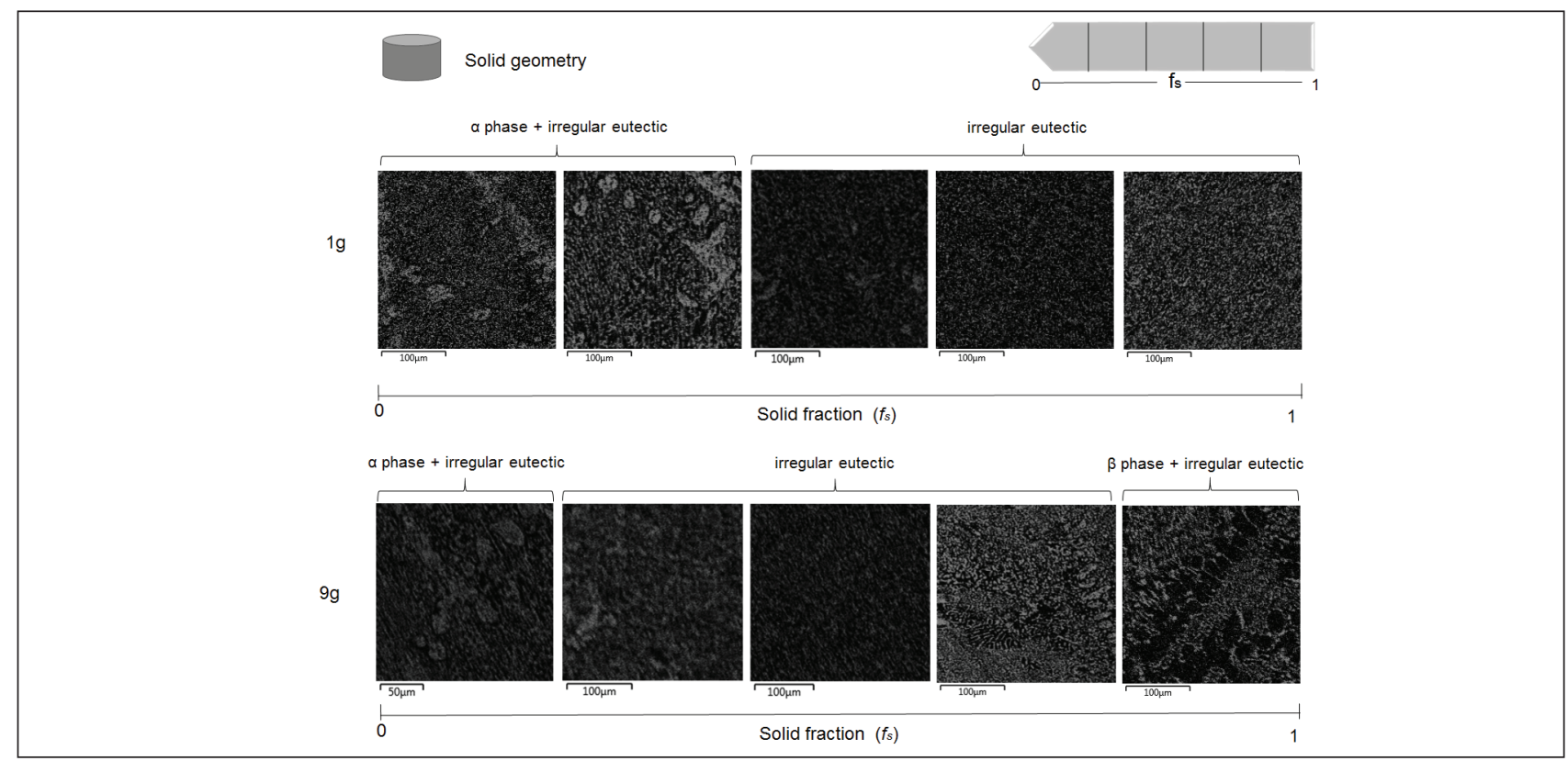

Figure 5: Lead composition profile for $1 \mathrm{~g}$ and $9 \mathrm{~g} \mathrm{PbSn}$ eutectic alloy analyzed by energy dispersive spectrometry (EDS). 


\section{ACKNOWLEDGMENTS}

The authors Tenório, P.I.G., and Toledo, R.C., are grateful to CAPES for the financial support.

\section{REFERENCES}

1. Freitas FE, Toledo RC, Poli AKS, An CY, Bandeira IN. The influence of high gravity in $\mathrm{PbSn}$ eutectic alloy. Materials Science Forum. 2016;869:631-636. Available from: https://doi.org/10.4028/www. scientific.net/MSF.869.631

2. Tenório PIG, Toledo RC, Freitas FE, Fumachi EF, Bandeira IN, An CY. Desenvolvimento de uma centrífuga para solidificação de ligas eutéticas em macrogravidade. In: Proceedings of $\mathrm{VI}$ Workshop em Engenharia e Tecnologia Espaciais; São José dos Campos, Brazil; 2015

3. An CY, Toledo RC, Boschetti C, Ribeiro MF, Bandeira IN Solidification of lead tin and lead telluride eutectic alloys in microgravity. Microgravity Science and Technology. 2014;25(5):267-273. Available from: https://doi.org/10.1007/ s12217-013-9348-7

4. An CY, Bandeira IN, Rowe DM, Min G. An exact density formula for substitutional solid solution alloys. Journal of Materials Science Letters. 1994;13(14):1051-1053. Available from: https:// doi.org/10.1007/BF00277036

5. Okamoto H, Schlesinger ME, Mueller EM. ASM Handbook: alloy phase diagrams. vol. 3. ASM International; 2016. 